\title{
Paleomagnetic Study of the Ashitaka Dike Swarm in Central Japan
}

\author{
Hideo Tsunakawa and Yozo Hamano* \\ Institute of Research and Development, Tokai University, Kanagawa 259-12, Japan \\ *Earthquake Research Institute, University of Tokyo, Tokyo 113, Japan
}

(Received May 11, 1987; Revised November 26, 1987)

\section{Introduction}

Secular variation is a significant characteristics of the geomagnetic field. Volcanic rocks are very useful to study paleosecular variation because of their stable thermoremanent magnetization although we obtain spot-reading data. Outcrops of many independent lavas are relatively easy to be found at hotspot areas such as oceanic islands but not in other regions. On the other hand a dike swarm usually occurs in volcanic regions as more than one hundred intrusions of subterranean volcanism. Its activity duration is regarded to be in the order of $10^{5}$ years similar to that of a stratovolcano (NAKAMURA, 1977). A dike swarm, therefore, probably records paleosecular variation of the geomagnetic field during the time span sufficient to reflect its nature. From this viewpoint we performed a paleomagnetic study on the Ashitaka dike swarm in the southern part of Central Japan and report its result in this paper.

\section{Geology of the Ashitaka Volcano and Experimental Procedures}

The Ashitaka volcano is located southward of Mt. Fuji and westward of Hakone volcano (Fig. 1). According to SAWAMURA (1955), it is constructed with two groups of strata; (1) lower part of older basaltic ejecta and (2) upper one of younger andesitic ejecta. Unfortunately there are no dating results of the Ashitaka volcanic rocks. However these rocks are covered by the Ashitaka loam, which is identified with the Kanto loam supplied by the Fuji and Hakone volcanoes. Volcanism of the Ashitaka is, therefore, considered to have taken place prior to those of the Fuji and Hakone volcanoes, namely several hundreds of thousand years. ISHIDA (1981) investigated the Ashitaka dike swarm intruding volcanic edifice and reported that more than two hundred outcrops of dikes are found as a radial pattern of strike directions. These dikes consist of basalt, pyroxene andesite and hornblende andesite, which occurred as correlatives of the older basaltic and younger andesitic ejecta.

Hand specimens from thirty-five dikes were oriented with a magnetic compass and collected by hand sampling along the dissected valley (Fig. 1). Their widths range from 0.2 to $4 \mathrm{~m}$. We chose these dikes which can be judged from strike direction to have intruded as independent sheets. One-inch core samples were cut from hand 


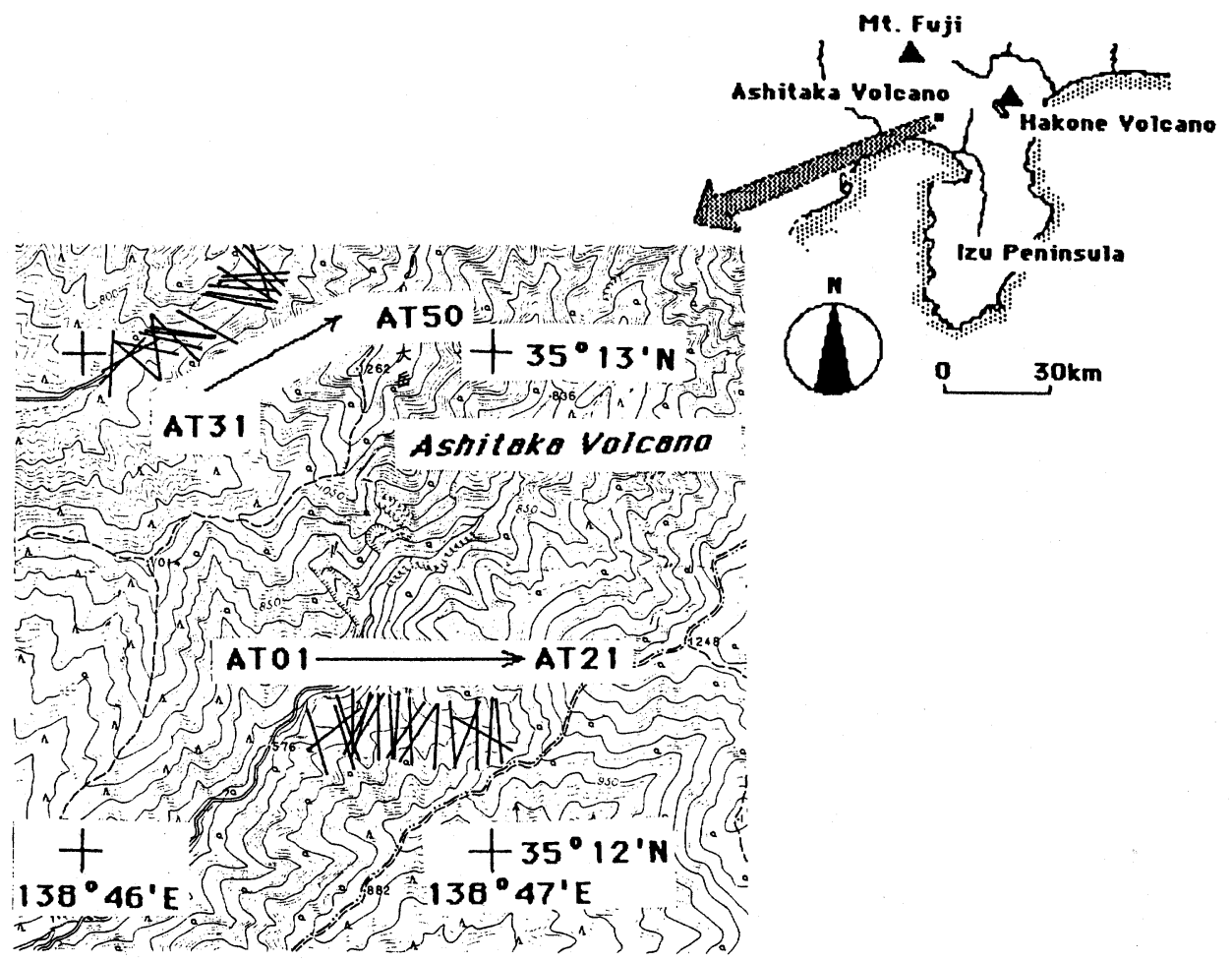

Fig. 1. Locality map of the Ashitaka dike swarm and sampling sites of AT01-50. Directions of solid bars denote strikes of dike intrusions.

specimens in the laboratory and remanent magnetization was measured with Schonstedt spinner magnetometer. Samples were subjected to alternating field (AF) demagnetization up to $100 \mathrm{mT}$ with steps of 2.5 to $20 \mathrm{mT}$. These samples are fresh volcanic rocks so that we consider AF demagnetization can reveal their primary magnetizations. A site mean direction of remanence was calculated for each step and the optimum one was determined with precision parameter $(k)$ based on Fisherian statistics (FISHER, 1953).

\section{Results and Discussion}

Paleomagnetic results are listed in Table 1. Remanent magnetizations of these samples are stable against AF demagnetization and their primary components were easily isolated from the secondary such as the viscous one (VRM). A typical result of $\mathrm{AF}$ demagnetization is shown in Fig. 2. Intensity of remanences is 1 to $24 \mathrm{~A} / \mathrm{m}$ and medium destructive fields (MDFs) range from 5 to $80 \mathrm{mT}$, most of which are within 10 
Table 1. Paleomagnetic results of the Ashitaka dike swarm. $N$ : number of measured samples, $I$ : inclination, $D$ : declination, $k$ : precision parameter, $a_{95}$ : radius of $95 \%$ confidence circle, ODF: optimum demagnetization field.

\begin{tabular}{|c|c|c|c|c|c|c|c|c|}
\hline \multirow[t]{2}{*}{ Site } & \multirow[t]{2}{*}{$N$} & \multirow[t]{2}{*}{$I$} & \multirow[t]{2}{*}{$D$} & \multirow[t]{2}{*}{$k$} & \multirow[t]{2}{*}{$a_{95}$} & \multirow[t]{2}{*}{ ODF } & \multicolumn{2}{|c|}{ VGP } \\
\hline & & & & & & & lat. & long. \\
\hline AT01 & 3 & $49.9^{\circ}$ & $-13.3^{\circ}$ & 41 & $19.4^{\circ}$ & $5 \mathrm{mT}$ & $78.0^{\circ} \mathrm{N}$ & $30.6^{\circ} \mathrm{E}$ \\
\hline AT02 & 3 & 45.1 & 9.0 & 106 & 12.1 & 15 & 78.5 & 274.3 \\
\hline AT03 & 3 & 66.5 & 8.2 & 343 & 6.7 & 15 & 75.0 & 160.1 \\
\hline AT04 & 4 & 41.5 & -11.3 & 37 & 15.4 & 40 & 75.0 & 2.7 \\
\hline AT05 & 3 & 62.7 & 21.9 & 639 & 4.9 & 20 & 71.0 & 194.2 \\
\hline AT06 & 3 & 37.0 & 3.2 & 79 & 14.0 & 10 & 75.2 & 307.2 \\
\hline AT07 & 4 & 27.7 & -21.3 & 496 & 4.1 & 15 & 62.0 & 7.1 \\
\hline AT08 & 4 & 41.5 & -3.2 & 92 & 9.6 & 15 & 78.3 & 333.4 \\
\hline AT09 & 4 & 48.3 & 8.9 & 83 & 10.1 & 15 & 80.4 & 264.5 \\
\hline AT10 & 4 & 70.4 & -7.6 & 80 & 10.3 & 15 & 70.0 & 125.9 \\
\hline AT11 & 3 & 56.2 & 20.7 & 438 & 5.9 & 20 & 73.6 & 217.4 \\
\hline AT12 & 3 & 44.5 & -10.5 & 125 & 11.1 & 10 & 77.2 & 6.7 \\
\hline AT13 & 4 & 48.3 & 21.4 & 71 & 11.0 & 20 & 71.0 & 240.8 \\
\hline AT14 & 4 & 58.5 & -6.5 & 91 & 9.7 & 30 & 83.4 & 88.6 \\
\hline AT 15 & 4 & 53.1 & -3.0 & 83 & 10.1 & 5 & 87.1 & 18.4 \\
\hline AT16 & 4 & 63.3 & -11.7 & 102 & 9.2 & 10 & 76.9 & 99.3 \\
\hline AT 17 & 4 & 60.2 & 9.8 & 104 & 9.1 & 40 & 80.3 & 188.5 \\
\hline AT18 & 4 & 55.9 & -19.7 & 96 & 9.5 & 5 & 74.0 & 59.0 \\
\hline AT 19 & 4 & 51.8 & -3.3 & 170 & 7.1 & 10 & 86.1 & 4.7 \\
\hline AT20 & 4 & 33.9 & -9.4 & 126 & 8.2 & 5 & 71.4 & 347.8 \\
\hline AT21 & 3 & 52.5 & 16.0 & 253 & 7.8 & 40 & 76.6 & 233.2 \\
\hline AT33 & 5 & 47.1 & -0.7 & 89 & 8.2 & 5 & 83.0 & 323.7 \\
\hline AT36 & 5 & 30.7 & 5.0 & 30 & 14.1 & 5 & 70.8 & 304.2 \\
\hline AT38 & 5 & 47.9 & -16.4 & 234 & 5.0 & 20 & 74.8 & 29.1 \\
\hline AT39 & 5 & 54.4 & -17.6 & 112 & 7.3 & 20 & 75.6 & 52.5 \\
\hline AT40 & 5 & 48.4 & -19.8 & 141 & 6.5 & 10 & 72.3 & 35.0 \\
\hline AT41 & 4 & 33.6 & -11.3 & 132 & 8.0 & 10 & 70.4 & 352.4 \\
\hline AT43 & 4 & 42.3 & -25.5 & 76 & 10.6 & 5 & 65.5 & 29.6 \\
\hline AT44 & 4 & 46.3 & -5.5 & 164 & 7.2 & 20 & 81.1 & 351.8 \\
\hline AT45 & 4 & 44.2 & -9.1 & 80 & 10.3 & 5 & 77.9 & 1.2 \\
\hline AT46 & 5 & 43.3 & -28.1 & 171 & 5.9 & 15 & 63.9 & 34.0 \\
\hline AT47 & 4 & 56.9 & 25.0 & 43 & 14.2 & 20 & 69.8 & 215.0 \\
\hline AT48 & 5 & 43.9 & -6.7 & 86 & 8.3 & 20 & 78.9 & 351.5 \\
\hline AT49 & 5 & 52.2 & -5.7 & 101 & 7.6 & 5 & 84.7 & 23.4 \\
\hline AT50 & 5 & 55.1 & -14.1 & 370 & 4.0 & 15 & 78.6 & 54.6 \\
\hline \multirow[t]{2}{*}{ Mean } & 35 & 49.8 & -4.6 & 37.4 & 3.9 & & & \\
\hline & & & & 30.0 & 4.3 & & 84.9 & 4.1 \\
\hline
\end{tabular}

to $40 \mathrm{mT}$. Site mean directions of remanences in optimum AF step are projected in equal area net of Fig. 3(a) and their virtual geomagnetic poles (VGPs) are in Fig. 3(b). As seen in Fig. 3(a), all of the samples have normal polarity. As mentioned earlier, the Ashitaka dike swarm occurred several hundreds of thousand years ago. Hence these 


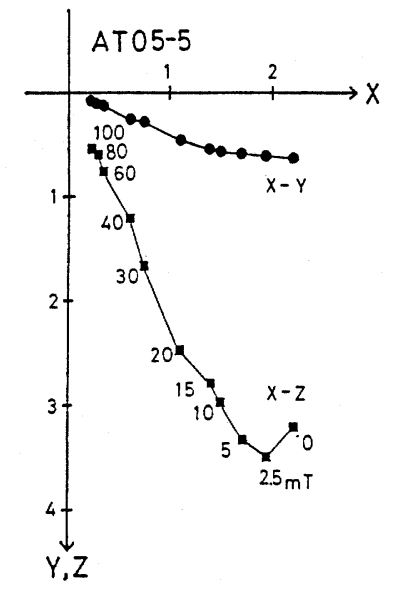

Fig. 2. Vector diagram of AF demagnetization for the sample AT05-5 from the AT05 dike. $X$ : north, $Y$ : east, $Z$ : down. Unit of axes is $1 \mathrm{~A} / \mathrm{m}$. Numerical values denote steps of AF demagnetization.

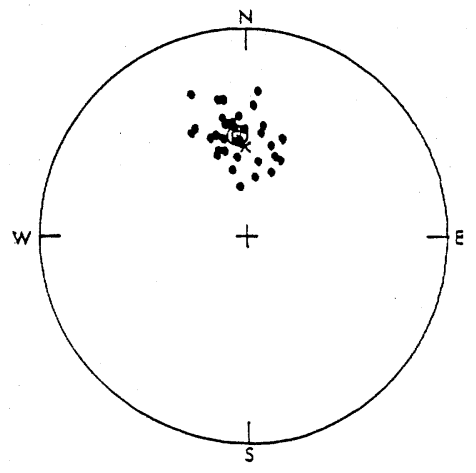

Field Direction

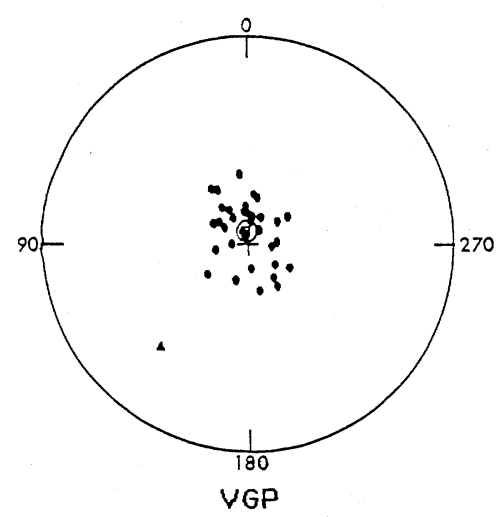

Fig. 3. Equal area projections of field directions and of VGPs for site means of AT01-50. Open squares: mean directions between sites with $95 \%$ confidence circles, cross: geocentric axial dipole field, triangle: locality of the Ashitaka dike swarm.

dikes were presumably formed during the Brunhes epoch.

Mean field direction between sites is calculated to be $I=49.8^{\circ}$ and $D=-4.6^{\circ}$ with a $95 \%$ confidence circle $\left(a_{95}\right)$ of $3.9^{\circ}$. This direction almost coincides with geocentric axial dipole field of $I=54.7^{\circ}$ and $D=0^{\circ}$ although it shows slight shift of low inclination and westward declination. Its corresponding VGP is located at $\left(84.9^{\circ} \mathrm{N}\right.$, $4.1^{\circ} \mathrm{E}$ ) with $a_{95}$ of $4.3^{\circ}$, which is close to the geographical north pole. Angular 
standard deviation (ASD) between sites (SB), which is isolated from the total ASD by subtracting within-site ASD, is calculated to be $13.8^{\circ}$. Its $95 \%$ confidence limit can be calculated from the table presented by Cox (1969) and the result shows lower $95 \%$ limit $\left(\mathrm{SB}^{1}\right)$ of $11.8^{\circ}$ and upper one $\left(\mathrm{SB}^{\mathrm{u}}\right)$ of $16.4^{\circ}$. HEKI (1983) reported ASD value for Japanese volcanic rocks younger than 40,000 years $\mathrm{BP}$ as $\mathrm{SB}=13.9^{\circ}$ with $\mathrm{SB}^{1}=11.7^{\circ}$ and $\mathrm{SB}^{\mathrm{u}}=16.9^{\circ}$, which is quite similar to that of the present study. TSUNAKAWA et al. (1985) reported ASD value of the Shimokura dike swarm in Northeast Japan at $8 \mathrm{Ma}$ reversal epoch as $\mathrm{SB}=14.1^{\circ}$ with $\mathrm{SB}^{1}=11.4^{\circ}$ and $\mathrm{SB}^{\mathrm{u}}=18.7^{\circ}$. Therefore angular standard deviation of about $14^{\circ}$ seems to be representative value for geomagnetic paleosecular variation of the Japanese region for a time interval in the order of $10^{5}$ years. This value of $\mathrm{SB}$ agrees well with that in Japan over the Brunhes epoch $\left(\mathrm{SB}=13.7^{\circ}, \mathrm{SB}^{1}=12.3^{\circ}, \mathrm{SB}^{\mathrm{u}}=15.4^{\circ}\right)$ compiled by MCELHINNY and MERRILL (1975). However MCELHINNY and MERRILL (1975) used the paleomagnetic and archeomagnetic data reported by KINOSHITA (1970) and OZIMA and AOKI (1972), large part of which have ages younger than one hundred of thousand years. Hence their reported ASD has a problem whether or not it truely represents the paleosecular variation of the whole time span of the Brunhes epoch in Japan. HEKI (1983) thought that about $14^{\circ}$ of $\mathrm{SB}$ in Japan agrees with the global trend $\left(\mathrm{SB}=14.8^{\circ}, \mathrm{SB}^{1}=13.9^{\circ}, \mathrm{SB}^{\mathrm{u}}=15.8^{\circ}\right)$ obtained for the latitude range of $31^{\circ}-45^{\circ}$ from world-wide data after MCELHINNY and MERRILL (1975) and that local tectonic disturbances cause relatively larger value of ASD for the last $5 \mathrm{Ma}$ in Japan $\left(\mathrm{SB}=18.3^{\circ}, \mathrm{SB}^{1}=19.7^{\circ}, \mathrm{SB}^{\mathrm{u}}=17.1^{\circ}\right.$; MCELHINNY and MERRILL, 1975). However the Japanese ASD value of the last $5 \mathrm{Ma}$ is not different from the global trend of $31^{\circ}-45^{\circ}$ latitudes $\left(\mathrm{SB}=16.7^{\circ}, \mathrm{SB}^{1}=17.5^{\circ}\right.$, $\mathrm{SB}^{\mathrm{u}}=15.9^{\circ}$; MCELHINNY and MERRILL, 1975) at the $95 \%$ confidence level so that $\mathrm{SB}$ of about $18^{\circ}$ may conceivably indicate secular variation for the time span longer than $10^{5}$ years. Accordingly it is speculated that there is possibly secular variation with a period longer than $10^{5}$ years.

\section{Summary}

We carried out paleomagnetic study on the Ashitaka dike swarm in southern part of Central Japan to investigate paleosecular variation of geomagnetic field in the Bruhnes epoch. Thirty-five independent dikes were sampled and yielded stable components of remanent magnetization. These VGPs show a mean direction located nearly at the geographical north pole with ASD of $13.8^{\circ}$. Results of the present and previous studies suggest that about $14^{\circ}$ of ASD is characteristic value of geomagnetic paleosecular variation in Japan for a time interval of $10^{5}$ years.

We thank Dr. T. Ishida (Yamanashi Univ.) for providing information about localities of good outcrops. We also thank Prof. M. Kono (Tokyo Inst. Tech.) and Drs. M. Takayanagi and E. Kikawa (Tokyo Univ.) for help in sampling. 


\section{REFERENCES}

Cox, A., Confidence limits for the precision parameter $k$, Geophys. J. R. Astr. Soc., 18, 545-549, 1969. Fisher, R. A., Dispersion on a sphere, Proc. R. Soc., Ser. A., 217, 295-305, 1953.

HEKI, K., Paleomagnetic study of the Higashi-Izu monogenetic volcano group and pyroclastic flow deposits in Kagoshima prefecture: paleosecular variation during the last 40,000 years in Japan, $J$. Geomag. Geoelectr., 35, 383-390, 1983.

IsHiDA, T., Radial patterns of the dike swarms in Ashitaka volcano, Central Japan, Mem. Fac. Lib. Educ., Yamanashi Univ., 32, 88-95, 1981.

KinoshitA, H., Lists of archeomagnetic and paleomagnetic results, -1950-1970, in Japan-, J. Geomag. Geoelectr., 22, 507-550, 1970.

McElhinny, M. W. and R. T. Merrill, Geomagnetic secular variation over the past 5 m.y., Rev. Geophys. Space Phys., 13, 687-708, 1975.

NaKamura, K., Volcanoes as possible indicators of tectonic stress orientation-principle and proposal, $J$. Volcanol. Geotherm. Res., 2, 1-16, 1977.

OzIMA, M. and Y. AoKI, Quiet secular variation in Japan during the last 9,500 years, J. Geomag. Geoelectr., 24, 471-477, 1972.

Sawamura, K., Explanetary text of the geological map on scale 1:75,000 "Numazu", 1/75,000 Geological Map "Numazu", Geol. Surv. Japan, 1955 (in Japanese).

Tsunakawa, H., K. Hekl, and K. Amamo, Paleomagnetism of the Shimokura dike swarm in Northeast Japan, J. Geomag. Geoelectr., 37, 979-985, 1985. 